\title{
Effect of forest site types on the exchangeable and water-soluble cations distribution in the soil profiles
}

\author{
Wpływ typu siedliska na skład kompleksu sorpcyjnego \\ i wyciągów wodnych w profilach gleb leśnych
}

*Dr hab. Grażyna Porębska, dr hab. Apolonia Ostrowska, prof. nadzw. -

Institute of Environmental Protection - National Research Institute, Krucza

5/11d St., 00-548 Warszawa, e-mail: grazyna.porebska@ios.edu.pl

Keywords: base cations, $\mathrm{Ca} / \mathrm{Al}$ ratio, coniferous sites, deciduous sites

Słowa kluczowe: kationy zasadowe, wskaźnik Ca/Al, siedliska borowe, siedliska lasowe

\begin{abstract}
The aim of this research was to assess the impact of forest site types on the ionic composition of the soil sorption complex and soil water extracts in a soil profile. Three forest site types: coniferous forest (CF), coniferous-deciduous forest (CDF), and deciduousconiferous forest (DCF), were selected for the studies. Three dominant soil types were distinguished on the studied plots: Haplic Podzol, Dystric Arenosol, and Dystric Cambisol. Calcium (Ca), magnesium $(\mathrm{Mg})$, potassium $(\mathrm{K})$, sodium $(\mathrm{Na})$, and aluminium (Al) in the soil sorption complex and soil water extracts were determined. $\mathrm{Ca}$ is a dominant cation in the soil sorption complex in organic horizon, while Al in mineral soil horizons. The differences between forest site types in ionic composition of soil water extracts were observed, mainly in the organic horizon and the horizons below the rooting zone. The vegetation affected the $\mathrm{Ca} / \mathrm{Al}$ and base cations to $\mathrm{Al}$ molar $(\mathrm{BC} / \mathrm{Al})$ ratios. The $\mathrm{Ca} / \mathrm{Al}$ and the $\mathrm{BC} / \mathrm{Al}$ molar ratios increased in the sequence of sites: $\mathrm{CF}<\mathrm{CDF}<\mathrm{DCF}$.
\end{abstract}

๑) IOŚ-PIB

\section{INTRODUCTION}

Impact of tree species on carbon and nitrogen cycles and on soil properties, including soil $\mathrm{pH}$, cation exchange capacity (CEC), and soil solution chemistry was studied by many authors [Fujinuma et al. 2005; Oulehle and Hruška 2005; Hansen et al. 2007; Bonifacio et al. 2008; Mareschal et al. 2010; Collignon et al. 2011; Lindroos et al. 2011; Mueller et al. 2012; van der Heijden et al. 2013; Lu et al. 2014].

Although different tree species have different effects on the chemical properties of the soil and soil solution, it is difficult to separate the tree species effect from the effect of natural soil factors prevailing in a specific area, which, in turn, favour the growth of a certain tree species. Pine stands are common on dry sandy soil with naturally relatively low nutrient availability, while spruce and birch are common on more moist site types with usually higher fertility than on the dryer sites [Lindroos et al. 2011]. The stock of exchangeable nutrients can be influenced by the seasonal variations, particularly during the growing season when the nutrient uptake by the vegetation is important [Collignon et al. 2011].

The impact of the vegetation on the soil processes and their intensity is revealed in different way. Stand age and tree species

\section{Streszczenie}

Celem pracy było ustalenie czy i na ile pokrywa roślinna oddziałuje na skład kompleksu sorpcyjnego i ilość kationów przechodzących do roztworów wodnych oraz wartości wskaźnika Ca/Al. Badania przeprowadzono w trzech siedliskach: borze świeżym, borze mieszanym świeżym i lesie mieszanym świeżym, w których występują głównie gleby bielicowe typowe, rdzawe z cechami bielicowania i brunatne $z$ cechami bielicowania. Oznaczono $\mathrm{Ca}$, $\mathrm{Mg}, \mathrm{K}, \mathrm{Na}$ i Al w kompleksie sorpcyjnym i roztworach wodnych gleb z poszczególnych poziomów genetycznych. W kompleksie sorpcyjnym dominującym kationem w poziomie organicznym jest $\mathrm{Ca}$, natomiast w poziomach mineralnych Al. Zróżnicowanie składu jonowego roztworów wodnych między siedliskami stwierdzono głównie w poziomie organicznym i dolnych poziomach analizowanych gleb. Siedlisko wpływa na wartości wskaźników $\mathrm{Ca} / \mathrm{Al}$ i BC/Al. Wartości wskaźników zwiększają się w szeregu: bór świeży< bór mieszany świeży < las mieszany świeży.

affect the population of specific earthworms and the dynamics of plant litter transformation to soil organic matter (SOM) [Crow et al. 2009; Lu et al. 2012]. The SOM decomposition depends on, among others, temperature, moisture, and plant species activity, that is, root respiration and exudates production [Curiel Yuste et al. 2007]. Although Lindroos et al. [2003] reported that the weathering of minerals is the main factor shaping the soil profile, more corrected seems be a statement that the formation of the soil type is a result of a feedback between the minerals weathering and the vegetation impact. The intensity of these processes is determined by the quality of the SOM, the rate of SOM mineralisation, and leaching of the dissolved organic matter (DOM) with soil depth. Lindroos et al. [2003], however, have not found systematic differences between the spruce, pine, and birch stands depending on the presence of DOM in the soil solution, and enhance the ability of DOM to weathering of soil minerals. Generally, coniferous species produce and accumulate large amounts of very acidic organic matter and have a smaller percentage base saturation than hardwoods. Mareschal et al. [2010] stated, however, that it was difficult to classify the coniferous species, 
as the differences between them were not significant. Lindroos et al. [2011] showed that the tree species' effect on the chemistry of upper soil percolation water was small. On the contrary, the results of Lu et al. [2014] showed a strong interaction between soil quality, nutrient dynamics, and vegetation types.

Acidification of forest soils, especially in coniferous sites is a natural process resulting from an interaction between the soil and the vegetation. Soil acidification is measured, among others, by a ratio of base to acidic ions in the soil sorption complex and in the soil solution. Mostly, the Calcium/Aluminium (Ca/Al) molar ratio has been used to assess soil acidity and $\mathrm{Al}$ stress in forest ecosystems. Cronan and Grigal [1995] reported that the Ca/Al molar ratios of less than 1.0 caused a $50 \%$ risk of $\mathrm{Al}$ stress, whereas values less than or equal to 0.2 resulted in $\mathrm{Al}$ stress $100 \%$ of the time. Lower $\mathrm{Ca} / \mathrm{Al}$ ratios indicate an increase in $\mathrm{Al}$ solubility and lower base cation saturation in the soil. However, it is known that tree species characterise different vulnerability to Al stress [Boyce et al. 2013; Levia et al. 2015], and according to Göransson and Eldhuset [2001], growth limitation of some species may depend on the low content of nutrients.

This study focussed on the assessment of the distribution of exchangeable and water-soluble cations and of the ionic composition of the soil sorption complex and soil water extracts in soil profiles of different forest site types. The objectives of the study were to determine:

- the differentiation among soil horizons occurring in selected forest site types in terms of the ionic composition of soil sorption complex and soil water extracts;

- the differentiation of the $\mathrm{Ca} / \mathrm{Al}$ and base cations to $\mathrm{Al}(\mathrm{BC} / \mathrm{Al})$ indicators among forest site types.

\section{MATERIALS AND METHODS}

The study was conducted on the three research plots:


Forest (the LR plot, $53^{\circ} 68^{\prime} \mathrm{N}, 22^{\circ} 67^{\prime} \mathrm{E}$ ), and Borecka Forest (the PB plot, $54^{\circ} 12^{\prime} \mathrm{N}, 2^{\circ} 06^{\prime} \mathrm{E}$ ). On the PG plot, there were the following forest types, according to Matuszkiewicz [1962]: a coniferous forest (CF), a coniferous-deciduous forest (CDF), and a deciduous-coniferous forest (DCF); on the LR plot, there was mainly DCF sites with a small part of CF site; whereas on the PB plot, there were DCF site and also a deciduous forest (DF). In the $\mathrm{CF}$ site, the dominant species was Scots pine (Pinus sylvestris L.). In the CDF sites, the dominant species were Scots pine (Pinus sylvestris L.), Norway spruce (Picea abies (L.) Karst), and oak (Quercus robur L.). In the DCF sites, the dominating species included: oak (Quercus robur L.), beech (Fagus L.), hornbeam (Carpinus betulus L.), and Scots pine (Pinus sylvestris L.). In the DF site, the dominating species were hornbeam (Carpinus betulus L.), oak (Quercus robur L.), and Norway spruce (Picea abies (L.) Karst).

According to the World Reference Base for Soil Resources [WRB 2006], the following soil types were distinguished: Haplic Podzol in the CF and CDF sites on the PG plot, Dystric Arenosol in the DCF site on the LR and PB plots, Dystric Cambisol in the DCF site on the PG plot and in the DF site on the PB plot.

The soils in the CF and CDF sites developed from fluvioglacial or eolian sands, whereas the soils in the DCF and DF sites emerged from glacial boulder clays. All soils were moderately to strongly acidic. The characteristics of the sites are presented in Table 1, and the characteristics of the soil were discussed in the separable paper [Porębska and Ostrowska 2016].

On each plot, 10 to 12 soils profiles were dug, and soil samples were taken from the individual horizons down to the depth of the parent rock. For samples that had been air-dried and sieved through a 2-mm mesh, the following was determined: exchangeable base cations ( $\mathrm{Ca}, \mathrm{Mg}, \mathrm{K}$, and $\mathrm{Na}$ ) in $1 \mathrm{M} \mathrm{NH}_{4} \mathrm{OAc}$ extracts by the ICP-AES (Varian, VISTA-PRO, Australia), exchangeable acidity by titration of $1 \mathrm{M} \mathrm{KCl}$ extracts, and exchangeable $\mathrm{Al}$ in $1 \mathrm{M} \mathrm{KCl}$ extracts by the FAAS method (AA/ AE AAS-30, C.ZEISS JENOPTIC, Germany). The effective CEC was calculated as $\mathrm{Ca}^{2+}+\mathrm{Mg}^{2+}+\mathrm{K}^{+}+\mathrm{Na}^{+}+\mathrm{Al}^{3+}$ in $\mathrm{mmol}_{\mathrm{c}} \mathrm{kg}^{-1}$.

The soil water extracts were prepared by adding Mili- $Q$ water (at the $1: 3$ or $1: 10$ mass to volume ratio, respectively, for mineral and organic soils) to soil samples that had been air-dried and sieved, and then incubating the solutions for 10 days at $25^{\circ} \mathrm{C}$.

Table 1. Description of studied area

\begin{tabular}{|c|c|c|c|}
\hline Plot & Site type & Forest floor & Soil type \\
\hline \multirow[t]{3}{*}{$\begin{array}{l}\text { PG } \\
\text { plot }\end{array}$} & CF - Coniferous forest, Leucobryo-Pinetum & mosses, herbs, grasses & Haplic Podzol \\
\hline & CDF - Coniferous-decidous forest, Fago-Quercetum with pine & spruce, rowan-tree, bracken & Haplic Podzol \\
\hline & DCF - Deciduous-coniferous forest, Fago-Quercetum with pine & mosses, wood sorrel & Dystric Cambisol \\
\hline \multirow[t]{2}{*}{ LR plot } & CF - Coniferous forest, Leucobryo-Pinetum & mosses, herbs, grasses & Dystric Arenosol \\
\hline & DCF - Deciduous-coniferous forest, Querco-Pinetum & herbs, grasses, oak, spruce, hazel & Dystric Arenosol \\
\hline \multirow[t]{2}{*}{$\begin{array}{l}\text { PB } \\
\text { plot }\end{array}$} & DCF - Deciduous-coniferous forest, Querco roboris-Pinetum & $\begin{array}{c}\text { spruce, oak, hornbeam, mosses, } \\
\text { herbs }\end{array}$ & Dystric Arenosol \\
\hline & DF - Decidous forest, Tilio-Carpinetum & $\begin{array}{c}\text { hornbeam, maple, hazel, spruce, } \\
\text { herbs }\end{array}$ & Dystric Cambisol \\
\hline
\end{tabular}


After centrifuging $(6,000 \mathrm{rpm}$.$) the water extracts, the contents$ of $\mathrm{Ca}, \mathrm{Mg}, \mathrm{K}, \mathrm{Na}$, and $\mathrm{Al}$ were determined by the FAAS method. The sum of $\mathrm{Ca}+\mathrm{Mg}+\mathrm{K}+\mathrm{Na}+\mathrm{Al}$ in soil water extract (S-ss) in $\mathrm{mmol}_{\mathrm{c}} \mathrm{kg}^{-1}$ was calculated.

The results were presented as the mean values, for the individual horizons of the soils occurring in a given forest site type. The ion composition of soil sorption complex and soil water extracts, that is, shares of analysed elements in their sum in the soil (S-ex) and water extracts (S-ss) were considered. The mean values and standard deviations (SD) of the basic parameters were calculated.

\section{RESULTS}

As already described in the previous paper, the ionic composition of soil sorption complex and soil water extracts were differentiated within a soil type and among soil types [Porębska and Ostrowska 2016]. In this paper, we focussed on the differentiation between forest site types.

The S-ex value was significantly higher in the $\mathrm{O}$ horizons of soils in the DCF sites than in the soils of the CF and CDF sites (Table 2). The S-ex was dominated in all the sites by $\mathrm{Ca}$, followed by $\mathrm{Al}$ and $\mathrm{Mg}$ in the organic horizons of the CF and CDF sites, and by Mg in the DCF sites (Fig. 1). In the soil water extracts from the $\mathrm{O}$ horizons, the $\mathrm{S}$-ss values were the highest in the DCF sites and the lowest in the CF sites. In the S-ss, $\mathrm{K}$ dominated, followed by $\mathrm{Ca}$ and $\mathrm{Na}$ in the $\mathrm{CF}$ and CDF sites, while in the DCF sites, the dominant element was $\mathrm{Ca}$, followed by $\mathrm{K}$ and $\mathrm{Mg}$ (Fig. 1).

In the $A(A+A E)$ horizons, the $S$-ex values and their ionic composition were similar, irrespective of the site, with $\mathrm{Al}$ substantially prevailing over the base cations (Table 2, Fig. 1). The soil water extracts from these horizons in all the sites were dominated by $\mathrm{Al}$, wherein the share of $\mathrm{Al}$ was the largest in the CF sites and the smallest in the DCF sites (Fig. 1). The second largest share in the S-ss in the CF and DCF sites was $\mathrm{Na}$, and so was $\mathrm{Ca}$ in the CDF sites. The share of $\mathrm{Ca}$ in the S-ss in the DCF sites was twice higher than in the CF and CDF sites. Mg had the smallest share in the S-ss in all the sites.

The group of $\mathrm{B}$ horizons (Bhs, $\mathrm{Bv}$, and $\mathrm{Bws}$ ) varied depending on the soil type. However, the S-ex was dominated by Al, regardless of the horizon and forest site, and its shares in the S-ex were apparently higher than in the S-ss (Fig. 1).

The S-ex and S-ss values in the group of $\mathrm{BC}$ and $\mathrm{BvC}$ horizons, as well as in the $C$ horizon, were significantly higher in the DCF site than in the CDF and CF sites, wherein the variability of these horizons, expressed as its SD, were high (Table 2). Al was the dominant element of the S-ex and S-ss in BC + BvB horizons in all the sites, and its share in the S-ex was larger than in the S-ss. In the $\mathrm{C}$ horizons, a larger share of $\mathrm{Ca}$ than $\mathrm{Al}$ was observed in the S-ex in the CDF and DCF sites, whereas, conversely, in the

Table 2. Sum of exchangeable $\mathrm{Ca}, \mathrm{Mg}, \mathrm{K}, \mathrm{Na}$, and $\mathrm{Al}$ (mean $\pm \mathrm{SD}$ ) in soil (S-ex) and soil water extract (S-ss), Ca/Al-ex, Ca/Al-ss, BC/Al-ex (BC - base cations: Ca + $\mathrm{Mg}+\mathrm{K}+\mathrm{Na}$ ) and $\mathrm{BC} / \mathrm{Al}-\mathrm{ss}$ ratios in the soil and soil water extract, respectively, for soil horizons occuring in the coniferous forest (CF), coniferous-deciduous forest (CDF), and deciduous-coniferous forest (DCF) site types

\begin{tabular}{|c|c|c|c|c|c|c|c|c|}
\hline \multirow[t]{2}{*}{ Site } & \multirow[t]{2}{*}{ Horizon } & \multirow[t]{2}{*}{$n$} & S-ex & S-ss & \multirow[t]{2}{*}{ Ca/Al-ss } & \multirow[t]{2}{*}{ BC/Al-ss } & \multirow[t]{2}{*}{ CalAl-ex } & \multirow[t]{2}{*}{ BC/Al-ex } \\
\hline & & & \multicolumn{2}{|c|}{$\mathrm{mmol}_{\mathrm{c}} \mathrm{kg}^{-1}$} & & & & \\
\hline \multirow[t]{7}{*}{$\mathrm{CF}$} & $\mathrm{O}$ & 8 & $145.66 \pm 37.21$ & $6,46 \pm 1.71$ & 3,0 & 20,1 & 6,4 & 9,9 \\
\hline & $A E$ & 6 & $32.31 \pm 12.64$ & $1.16 \pm 0.51$ & 0,2 & 1,0 & 0,1 & 0,3 \\
\hline & $E$ & 2 & $7.04 \pm 3.23$ & $0,55 \pm 0.01$ & 0,2 & 1,0 & 0,2 & 0,4 \\
\hline & Bhs & 8 & $18.48 \pm 2.51$ & $0.95 \pm 0.24$ & 0,2 & 0,9 & 0,2 & 0,4 \\
\hline & Bv & 10 & $9.44 \pm 1.67$ & $0,55 \pm 0.65$ & 0,2 & 1,0 & 0,4 & 0,9 \\
\hline & $B C+B v C$ & 8 & $5.95 \pm 2.18$ & $0.27 \pm 0.18$ & 0,7 & 3,1 & 0,7 & 1,6 \\
\hline & C & 8 & $6.41 \pm 3.63$ & $0,36 \pm 0.30$ & 0,3 & 1,4 & 0,9 & 2,1 \\
\hline \multirow[t]{8}{*}{ CDF } & $\mathrm{O}$ & 15 & $122.45 \pm 30.78$ & $9.65 \pm 4.65$ & 4,0 & 16,2 & 7,4 & 11,2 \\
\hline & $A+A E$ & 11 & $35.61 \pm 17.27$ & $1.12 \pm 0.37$ & 0,5 & 2,2 & 0,2 & 0,4 \\
\hline & $E$ & 2 & $16.64 \pm 7.50$ & $0.84 \pm 0.22$ & 0,0 & 0,8 & 0,2 & 0,4 \\
\hline & $A B v$ & 4 & $23.03 \pm 6.35$ & $1.14 \pm 0.24$ & 0,7 & 1,8 & 0,2 & 0,6 \\
\hline & Bhs & 8 & $16.31 \pm 8.44$ & $0.83 \pm 0.28$ & 0,4 & 1,3 & 0,2 & 0,5 \\
\hline & Bv & 10 & $11.18 \pm 2.75$ & $0.42 \pm 0.11$ & 1,5 & 4,5 & 0,4 & 1,0 \\
\hline & $B C+B v C$ & 15 & $9.69 \pm 6.78$ & $0.52 \pm 0.30$ & 0,6 & 2,2 & 0,6 & 1,3 \\
\hline & C & 15 & $7.68 \pm 5.83$ & $0.37 \pm 0.11$ & 0,8 & 3,1 & 2,1 & 4,0 \\
\hline \multirow[t]{7}{*}{ DCF } & O & 2 & $269.00 \pm 20.07$ & $24.81 \pm 2.21$ & 19,3 & 60,7 & 32,4 & 47,9 \\
\hline & $A+A E$ & 5 & $35.88 \pm 19.34$ & $1,53 \pm 0.80$ & 0,7 & 3,1 & 0,2 & 0,5 \\
\hline & $A B$ & 2 & $53.40 \pm 6.65$ & $1.74 \pm 1.73$ & 26,2 & 65,1 & 1,0 & 1,6 \\
\hline & Bws & 4 & $48.05 \pm 41.73$ & $1.13 \pm 0.78$ & 0,7 & 2,9 & 1,0 & 1,4 \\
\hline & Bv & 2 & $10.96 \pm 1.76$ & $0.52 \pm 0.49$ & 0,7 & 2,3 & 0,2 & 0,5 \\
\hline & $B C+B v C$ & 7 & $43.69 \pm 55.84$ & $1.64 \pm 1.80$ & 1,2 & 4,6 & 2,2 & 3,2 \\
\hline & C & 7 & $41.30 \pm 51.66$ & $1.00 \pm 0.96$ & 1,7 & 6,6 & 4,1 & 5,8 \\
\hline
\end{tabular}

$\mathrm{n}$ - number of samples; SD - standard deviation 
CF (ex)

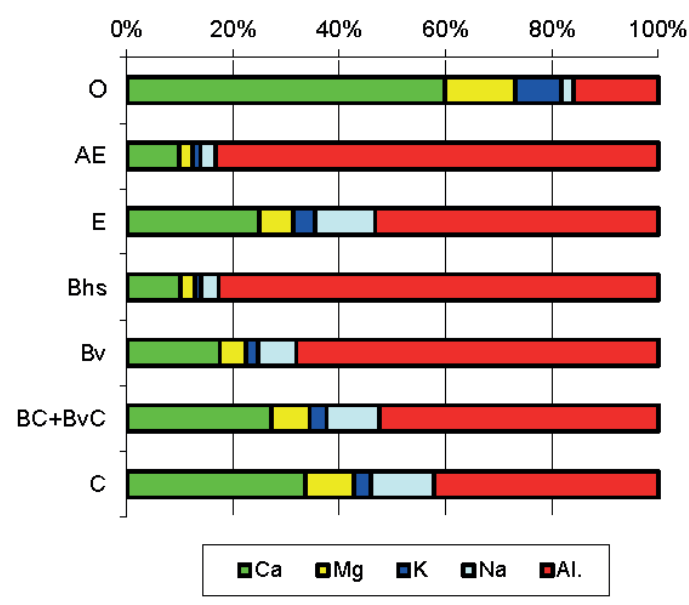

$\operatorname{CDF}(\mathrm{ex})$

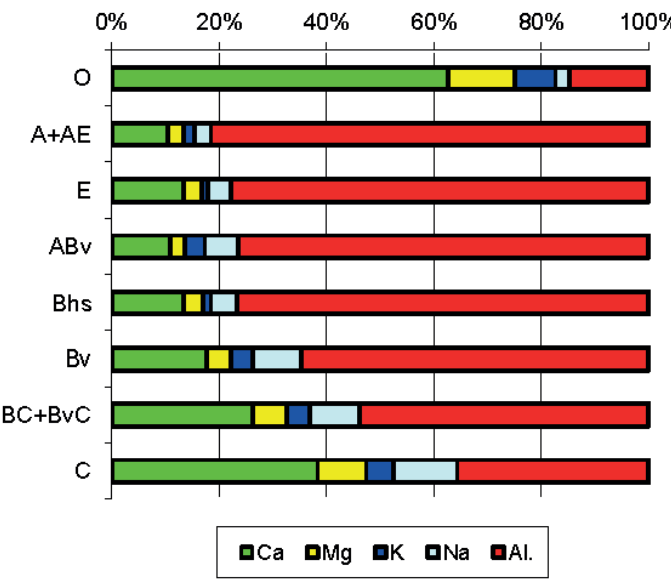

DCF (ex)

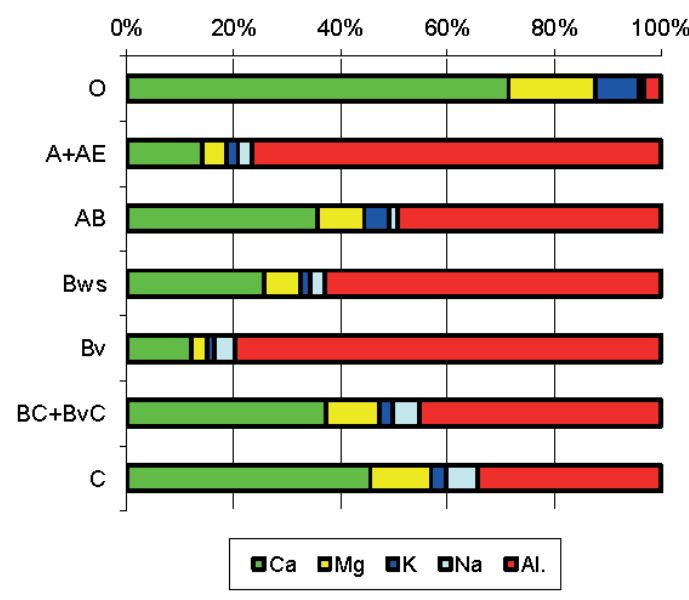

CF (ss)
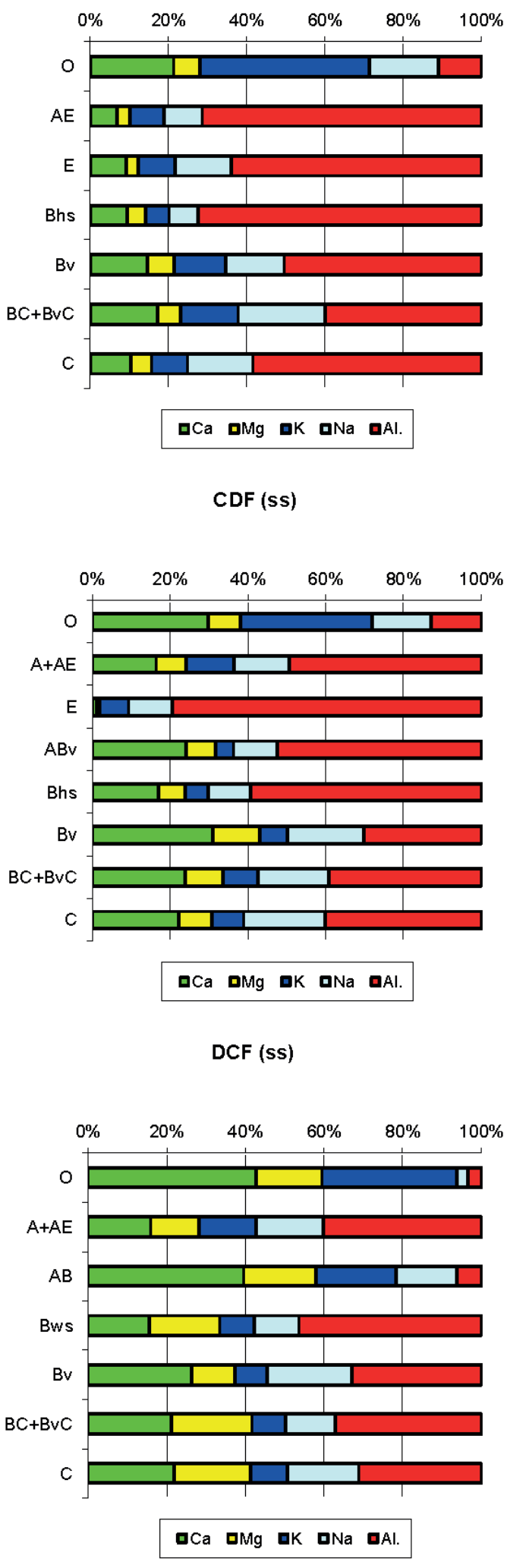

Figure 1. Ionic composition of the soil sorption complex (S-ex) and soil water extract (S-ss) for soil horizons in coniferous forest (CF), coniferous-deciduous forest (CDF), and deciduous-coniferous forest (DCF) site 
CF site, a larger share of Al than Ca was stated. In turn, the S-ss in the $\mathrm{C}$ horizons in all the sites was dominated by $\mathrm{Al}$, although $\mathrm{Mg}$ was found to have a significantly larger share in the DCF site than in the CDF and CF sites (Fig. 1).

Both, in the soil and in the soil water extracts of all groups of soil horizons, the values of the $\mathrm{Ca} / \mathrm{Al}$ and $\mathrm{BC} / \mathrm{Al}$ ratios increased in the sequence: $\mathrm{CF}<\mathrm{CDF}<\mathrm{DCF}$ (Table 2).

\section{DISCUSSION}

The relationships between forest site types and the soil are shaped by an interaction of the soil-forming materials, tree species in the stand, and the forest floor vegetation. It is hard to separate the impact of individual factors on soil properties, and it seems to be one reason for the inconsistency of the results obtained by the authors. Our results showed that the S-ex values in the upper soil horizons, with the exception of E horizon, were higher than in the deeper soil horizons. The S-ex values for soils of the main rooting layer, to the depth of $40-50 \mathrm{~cm}$, were increased in the order: $\mathrm{CF}<\mathrm{CDF}<\mathrm{DCF}$. The ionic composition of the soil sorption complex was under the influence of the vegetation for $\mathrm{O}$ and $\mathrm{A}$ horizons, while under the soil-forming processes for $\mathrm{BC} / \mathrm{BvC}$ and $C$ soil horizons. The differences between forest site types were occurred both, in the size of the soil sorption complex as well as in its ionic composition. The most acidic soils occurred in the CF sites. A higher share of $\mathrm{Al}$ in the soil sorption complex of coniferous than of mixed sites was related to the progressive depletion of soil Ca during acidification in the CF site.

The Ca/Al ratio in soil solution is used as an indicator of soil acidification and tree growth disturbance [Cronan and Grigal 1995]. Our previous research [Ostrowska et al. 2006, Ostrowska et al. 2008] as well as the data presented in this paper documented a relationship between the quality of the forest site and soil acidification. In the most depleted CF site, the values of the $\mathrm{Ca} / \mathrm{Al}$ in the soil water extracts and soil sorption complex were the lowest, and in the most richest DCF site, the $\mathrm{Ca} / \mathrm{Al}$ ratios were the highest.

According to Bonifacio et al. [2008], the water-extractable element concentrations did not show any significant difference between spruce and mixed coniferous-deciduous sites in organic layer or in mineral horizons. Our results indicated the impact of the forest site type in soil water extracts, mainly for the $O$ horizons. The S-ss values increased in the order: $\mathrm{CF}<\mathrm{CDF}<\mathrm{DCF}$, which was associated with an increase of foliage and herbaceous contribution in the forest floor and then in the litter. In the S-ss, $\mathrm{K}$ was dominated, easily leached from the organic matter. The share of $\mathrm{Ca}$ and $\mathrm{Al}$ in the S-ss were related to their content in the litter and the rate of its decay. In the CDF and DCF sites, the contribution of deciduous trees and herbaceous was increased. The organic matter of these species was more abundant in $\mathrm{Ca}$ and mineralised faster than needles, which was confirmed by the increasing share of $\mathrm{Ca}$ in the S-ss in the O horizon from CF to DCF. Similarly, increased share of $\mathrm{Ca}$ and decreased share of $\mathrm{Al}$ in the S-ss from A/AE horizons were observed from the CF to DCF sites.

Jung and Chang [2013] demonstrated a remarkable difference in the spatial pattern of soil chemistry and that the distance from tree boles affected the water-soluble base cation concentrations and $\mathrm{Ca} / \mathrm{Al}$ ratio, but not exchangeable base cation contents. Our results indicated that the sum of exchangeable cations in organic horizon of the DCF site was twice higher than in the CF and CDF sites, while the S-ex in AE horizon was similar, regardless the forest sites.

The results of the ionic composition of soil sorption complex indicated a distinct $\mathrm{Ca}$ depletion and $\mathrm{Al}$ mobilisation for all mineral horizons in coniferous and mixed stands. Even in the homogeneous forest sites, different soil types occurred, while the shares of the particular types determined the so-called mean soil quality in a given site, including the soil sorption complex and the soil solution. The coniferous sites were dominated by soils undergoing a more or less advanced podzolisation process, while Dystric Cambisols, which were more abundant, particularly in $\mathrm{Ca}$, prevailed in the DF sites. Thus, the abundance of base cations in soils and the values of the $\mathrm{Ca} / \mathrm{Al}$ and $\mathrm{BC} / \mathrm{Al}$ in the soil and the soil water extracts increased in the sequence: $\mathrm{CF}<\mathrm{CDF}<\mathrm{DCF}$.

The differences in base cations in the mineral soil under different tree species Fujinuma et al. [2005] explained by differences in the cation fluxes, such as canopy exchange, mineralisation, and weathering. The dominant base cation from mineralisation and weathering was $\mathrm{Na}$, followed by $\mathrm{Ca}$ and $\mathrm{Mg}$ for all tree species. According to Fujinuma et al. [2005], K may be fixed by clay minerals in the soil, as indicated the low content of $\mathrm{K}$ in deep leachates. Our results showed the largest share of $\mathrm{K}$ in the soil water extracts from the $\mathrm{O}$ horizon in the $\mathrm{CF}$ and $\mathrm{CDF}$ sites and the second one in the DCF site. In the deeper soil horizons, a relatively small share of $\mathrm{K}$ was observed.

Litter quality affected the $\mathrm{Ca} / \mathrm{Al}$ ratio apparently in organic horizon. SanClements et al. [2010] found in the O horizons under hardwood stands the $\mathrm{Ca} / \mathrm{Al}$ ratio ranged from 13.0 to 13.8 , while under softwood stands from 2.8 to 3.4. Our results also showed lower value of the Ca/Al ratio in the CF sites (6.4) than the DCF sites (32.4).

Both, in the soil and in the soil water extract, the largest values of these indicators were found in the $\mathrm{O}$ horizon, followed by the parent rock, with the lowest values in the $A E$ and $E$ horizons. As an exception, for the $A B$ horizon in the DCF site, a very low $\mathrm{Al}$ content in soil water extract was observed, and therefore, the $\mathrm{Ca} / \mathrm{Al}$ ratio was even higher than for $\mathrm{O}$ horizon.

\section{CONCLUSIONS}

- $\quad$ The differentiation of the size of the soil sorption complex and its ionic composition as well as the quantity and quality of soil water extracts was related to the site types and the soil-forming processes.

- The vegetation affected the values of S-ex and S-ss in the soil horizons of the plant rooting layer, while soil building material in the deeper soil horizons.

- In mineral soil horizons, the S-ex and S-ss values were dominated by Al; its share decreased from the CF to DCF site and the share of base cations, mainly Ca was increased.

- Both, in the soil and in the soil water extracts of all groups of soil horizons, the values of the $\mathrm{Ca} / \mathrm{Al}$ and $\mathrm{BC} / \mathrm{Al}$ ratios increased in the sequence of $\mathrm{CF}<\mathrm{CDF}<\mathrm{DCF}$ sites. 


\section{REFERENCES}

BONIFACIO E., CAIMI A., FALSONE G., TROFIMOV S. Y., ZANINI E., GODBOLD D. L. 2008. Soil properties under Norway spruce differ in spruce dominated and mixed broadleaf forests of the Southern Taiga. Plant and Soil 308: 149-159.

BOYCE R. L., SCHABERG P. G., HAWLEY G. J., HALMAN J. M., MURAKAMI P. F. 2013. Effects of soil calcium and aluminum on the physiology of balsam fir and red spruce saplings in northern New England. Trees 27: 1657-1667.

COLLIGNON CH., CALVARUSO CH., TURPAULT M-P. 2011. Temporal dynamics of exchangeable $\mathrm{K}, \mathrm{Ca}$ and $\mathrm{Mg}$ in acidic bulk soil and rhizosphere under Norway spruce (Picea abies Karst.) and beech (Fagus sylvatica L.) stands. Plant and Soil 349: 355-366.

CRONAN CH. S, GRIGAL D. F. 1995. Use of calcium/aluminum ratios as indicators of stress in forest ecosystems. Journal of Environmental Quality 24: 209-226.

CROW S. E., FILLEY T.R., MCCORMICK M., SZLÁVECZ K., STOTT D. E., GAMBLIN D., CONYERS G. 2009. Earthworms, stand age, and species composition interact to influence particulate organic matter chemistry during forest succession. Biogeochemistry 92:61-82.

CURIEL YUSTE J., BALDOCCHI D. D., GERSHENSON A., GOLDSTEIN A., MISSON L., WONG S. 2007. Microbial soil respiration and its dependency on carbon inputs, soil temperature and moisture. Global Change Biology 13: 20182035.

FUJINUMA R., BOCKHEIM J., BALSTER N. 2005. Base-cation cycling by individual tree species in old-growth forests of Upper Michigan, USA. Biogeochemistry 74: 357-376.

GÖRANSSON A., ELDHUSET T. D. 2001. Is the Ca+Mg+K/Al ratio in the soil solution a predictive tool for estimating forest damage? Water, Air, and Soil Pollution Focus 1: 57-74.

HANSEN K., VESTERDAL L., BASTRUP-BIRK A., BILLEHANSEN J. 2007. Are indicators for critical load exceedance related to forest condition? Water Air and Soil Pollution 183 293-308.

JUNG K., CHANG S. X. 2013. Soil and tree chemistry reflected the cumulative impact of acid deposition in Pinus banksiana and Populus tremuloides stands in the Athabasca oil sands region in western Canada. Ecological Indicators 25: 35-44.

LEVIA D. F., SHIKLOMANOV A. N., VAN STAN II J. T., SCHEICK C. E., INAMDAR S. P., MITCHELL M. J., McHALE P. J. 2015 Calcium and aluminum cycling in a temperate broadleaved deciduous forest of the eastern USA: relative impacts of tree species, canopy state, and flux type. Environ. Monit. Assess 187: 458, DOI 10.1007/s10661-015-4675-3.

LINDROOS A-J., BRÜGGER T., DEROME J., DEROME K. 2003. The weathering of mineral soil by natural soil solutions. Water, Air, and Soil Pollution 149: 269-279.

LINDROOS A-J., DEROME J., DEROME K., SMOLANDER A. 2011. The effect of Scots pine, Norway spruce and silver birch on the chemical composition of stand throughfall and upper soil percolation water in northern Finland. Boreal Environment Research 16: 240-250.
LU S., CHEN CH., ZHOU X., XU Z., BACON G. 2012. Responses of soil dissolved organic matter to long-term plantations of three coniferous tree species. Geoderma 170: 136-143.

LU X., TODA H., DING F., FANG S., YANG W., XU H. 2014. Effect of vegetation types on chemical and biological properties of soils of karst ecosystems. European Journal of Soil Biology 61: 49-57.

MARESCHAL L., BONNAUD P., TURPAULT M. P., RANGER J. 2010. Impact of common European tree species on the chemical and physicochemical properties of fine earth: an unusual pattern. European Journal of Soil Science 61: 14-23.

MATUSZKIEWICZ W. 1962. Zur Systematik der natürlichen Kiefernwälder des mittel- und osteuropäischen Flachlandes. Mitt. Florist.-Soziol. Arbeitsgem. N.F. 9: 145-186.

MUELLER K. E., EISSENSTAT D. M., HOBBIE S. E., OLEKSYN J., JAGODZINSKI A. M., REICH P. B., CHADWICK O. A., CHOROVER J. 2012. Tree species effects on coupled cycles of carbon, nitrogen, and acidity in mineral soils at a common garden experiment. Biogeochemistry 111: 601-614.

OSTROWSKA A., PORĘBSKA G., SIENKIEWICZ J., BORZYSZKOWSKI J., KRÓL H. 2006. Soil and vegetation properties in the monitoring of forest environment. Monograph. IOŚ Warszawa, 159 p. [in Polish].

OSTROWSKA A., PORĘBSKA G., GAWLIŃSKI S. 2008. Relations between the field of pine and $\mathrm{Ca} / \mathrm{Al}$ ratio in the growth environment and plants. Polish Journal of Environmental Studies 17: 917-923.

OULEHLE F., HRUŠKA J. 2005. Tree species (Picea abies and Fagus Sylvatica) effects on soil water acidification and aluminium chemistry at sites subjected to long-term acidification in the Ore Mts., Czech Republic. Journal of Inorganic Biochemistry 99: 1822-1829.

PORĘBSKA G., OSTROWSKA A. 2016. Relationships between exchangeable and water soluble cations in the forest soil. Ochrona Środowiska i Zasobów Naturalnych Vol. 27 No 3(69): 1-7.

SanCLEMENTS M. D., FERNANDEZ I. J., NORTON S. A. 2010. Soil chemical and physical properties at the Bear Brook Watershed in Maine, USA. Environmental Monitoring and Assessment 171: 111-128.

Van der HEIJDEN G., LEGOUT A., POLLIER B., MARESCHAL L., TURPAULT M-P., RANGER J., DAMBRINE E. 2013. Assessing $\mathrm{Mg}$ and $\mathrm{Ca}$ depletion from broadleaf forest soils and potential causes - A case study in the Morvan Mountains. Forest Ecology and Management 293: 65-78.

WRB - World Reference Base for Soil Resources (2006). FAO, Rome. 